\title{
Diversity and traditional use of shade trees in agroecological coffee plantations
}

\author{
Sandra Ramos Reyes ${ }^{1}$ \\ Ma. Antonia Pérez Olvera ${ }^{*}$ \\ Gisela Illescas Palma ${ }^{2}$ \\ Juan Antonio Cruz Rodríguez ${ }^{2}$ \\ Heike Vibrans ${ }^{1}$ \\ Diego Flores Sánchez'
}

\begin{abstract}
Coffee plantations under shade present high diversity and a complex composition linked to socio-environmental conditions. In addition, the identity and culture of coffee families influence the richness of trees, allowing the use and conservation of the ecosystem services. This research had as objectives: to identify the species of shade trees and their main uses, in agroecological coffee plantations of the municipalities of Amatlán de Los Reyes (AMR) and Ixhuatlán del Café (IXC), Veracruz, as well as to estimate the alpha and beta diversity indices. This project was carried out with a Participatory Action Research approach. To identify shade trees in the coffee plantation, participatory transects were conducted, and a questionnaire was applied. Forty eight species of shade trees were registered in AMR and 102 species in IXC, grouped into 25 and 35 botanical families respectively. The Shannon-Wiener index was estimated (3.04 for AMR and 3.59 for IXC; Estimate SWin8.2.0) values considered as high, however, at an individual level (coffee plantation per family), these are poorly diversified and share a small number of species. The tree species most used are: chalahuite (Inga vera), avocado (Persea americana) and ixpepe (Trema micrantha) and its uses are: firewood, food, construction and medicinal.
\end{abstract}

Keywords: Agroecosystem coffee, coffee under shade, local diversity, native trees.

\section{Diversidad y uso tradicional de árboles de sombra en cafetales agroecológicos}

\section{Resumen}

El cafetal bajo sombra presenta diversidad alta y compleja composición ligada a condiciones socioambientales. La identidad y cultura de las familias cafetaleras influye en la riqueza de árboles mediante el aprovechamiento y conservación de los servicios ecosistémicos. La investigación tuvo como objetivos: Identificar las especies de árboles de sombra y sus usos principales en cafetales agroecológicos de los municipios de Amatlán de los Reyes (AMR) e Ixhuatlán del Café (IXC), Veracruz, así como estimar los índices de diversidad alfa y beta. Este proyecto se realizó con Investigación Acción Participativa, con un enfoque mixto. Para la identificación de árboles de sombra en el cafetal, se realizaron transectos participativos, y la aplicación de un cuestionario. Se registraron 48 especies de árboles de sombra en AMR y 102 especies en IXC, agrupadas en 25 y 35 familias botánicas respectivamente. Se calculó el índice de Shannon-Wiener (3.04 para AMR y 3.59 para IXC; Estimate SWin8.2.0), valores considerados altos; sin embargo, a nivel individual (cafetal por familia), estos son poco diversificados y comparten un número reducido de especies. Las especies arbóreas más utilizadas son: chalahuite (Inga vera), aguacate (Persea americana) y xochicahuitl (Trema micrantha); y sus usos son: leña, alimento, construcción y medicinales.

Palabras clave: Agroecosistema cafe, café a la sombra, diversidad local, árboles nativos.

'Colegio de Postgraduados, Agroecología y Sustentabilidad, campus Montecillo. Carretera México-Texcoco, km 36.5, Montecillo, Texcoco, Estado de México, México. C.P. 56230.

2Vinculación y Desarrollo Agroecológico de Café A.C.-VIDA A.C. Bucareli 5 Ixhuatlán del Café, Ixhuatlán del Café, C.P. 94180, Veracruz, México.

*Corresponding author: molvera@colpos.mx

Received: September 10, 2019.

Accepted: December 20, 2019. 


\section{Introduction}

Measuring biodiversity within an agroecosystem is key to know how it functions, it is managed and preserved (Travieso-Bello \& Ros, 2011). Biodiversity is understood as the variety and abundance of species in a study area, which can be measured through indices developed according to the richness of species and homogeneity in their distribution (Magurran, 2004). Indigenous peoples in Mexico shelter high levels of biodiversity in their territories (Boege, 2003). The shade coffee agroecosystem is characterized by its diverse composition of trees (Florez, J. A., Muschler, R., Harvey, C., Finegan, B., \& Roubik, D. W., 2002, Hernández M. F., Licona V., A. L., Pérez P., E., Cisneros S., V. M., \& Díaz C. S., 2012). In the specific case of the central region of the state of Veracruz, coffee plantations are altitudinally superimposed with cloud forests, considered as the forests with higher diversity per area (Williams-Linera, G., R. Manson, H., \& Isunza V., E., 2002; FranciscoVentura, E., Menchaca-García, R. A., Toledo-Aceves, T., \& Krömer, T., 2018). Its structure and geographical location makes it an important agroecosystem in biodiversity conservation, additionally, the low impact of the traditional management of coffee plantations preserves a complex vegetation structure which contributes to the stability of the ecosystem (Manson, R. H., Contreras H., A., \& Barrera F., L., 2008; Pérez-Fernández et al., 2017).

Ethnobotanic studies about shade tree diversity in the coffee agroecosystem (Martínez, M. Á., Evangelista, V., Basurto, F., Martínez, M., \& Cruz-Rivas, A. 2007; Jasso-Arriaga, 2019) show the traditional use of native trees as a strategy to preserve the processes that maintain the ecosystemic services that help enrichen regional diversity (Sánchez H., S., Mendoza B., M. Al. I., \& García H., R. V. 2017, Delgado D., M., Loureiro S., J. A., \& Alcántara B., F. A. 2018). In this regard, agroecology, seen as a comprehensive and practical science, resumes the traditional management of biodiversity and ecological functionality, and it enables the appreciation of peasant families' knowledge (Sevilla-Guzmán \& Woodgate, 2013); which highlight the need to promote the use of traditional practices and revalue the role of the communities in biodiversity management to promote the equilibrium between

\section{Introducción}

La medición de la biodiversidad dentro de un agroecosistema es fundamental para conocer su funcionamiento, manejo y conservación (Travieso-Bello \& Ros, 2011). La biodiversidad se entiende como la variedad y abundancia de especies en un área de estudio, la cual se puede medir a través de índices desarrollados de acuerdo a la riqueza de especies y homogeneidad en su distribución (Magurran, 2004). Los pueblos indígenas de México albergan en sus territorios altos niveles de biodiversidad (Boege, 2003). El agroecosistema café bajo sombra, se ha caracterizado por ser diverso en su composición de árboles (Florez, J. A., Muschler, R., Harvey, C., Finegan, B., \& Roubik, D. W., 2002, Hernández M. F., Licona V., A. L., Pérez P., E., Cisneros S., V. M., \& Díaz C. S., 2012). En el caso específico de la región centro del estado de Veracruz, los cafetales se sobreponen altitudinalmente con el bosque mesófilo de montaña, considerado como el bosque con mayor diversidad por unidad de superficie (Williams-Linera, G., R. Manson, H., \& Isunza V., E., 2002; Francisco-Ventura, E., Menchaca-García, R. A., Toledo-Aceves, T., \& Krömer, T., 2018). Tanto su estructura y ubicación geográfica hacen que sea un agroecosistema importante en la conservación de la biodiversidad, además, el bajo impacto del manejo tradicional en el cafetal conserva una estructura vegetal compleja que contribuye a la estabilidad del ecosistema (Manson, R. H., Contreras H., A., \& Barrera F., L., 2008; Pérez-Fernández et al., 2017).

Estudios etnobotánicos y sobre diversidad de árboles de sombra en el agroecosistema café (Martínez, M. Á., Evangelista, V., Basurto, F., Martínez, M., \& Cruz-Rivas, A. 2007; Jasso-Arriaga, 2019) exponen el uso tradicional de árboles nativos como una estrategia para preservar los procesos que mantienen los servicios ecosistémicos que ayudan a enriquecer la diversidad regional (Sánchez H., S., Mendoza B., M. Al. I., \& García H., R. V. 2017, Delgado D., M., Loureiro S., J. A., \& Alcántara B., F. A. 2018). En este sentido, la agroecología, vista como ciencia integral y como práctica, retoma el manejo tradicional de la biodiversidad y su funcionalidad ecológica y permite apreciar el conjunto de saberes de las familias campesinas (SevillaGuzmán \& Woodgate, 2013); en la cual se remarca la necesidad de promover el uso de prácticas tradicionales y revalorar el papel de las comunidades en el 
production and conservation of the ecosystem, it also uses the alboreal richness which translates into environmental, economic, social and cultural benefits such as the construction of food sovereignty (Sevilla-Guzmán \& Woodgate, 2013; Martínez-Torres \& Rosset, 2015).

A loss of $40 \%$ of cloud forest is estimated for Veracruz, mainly due to the change in the use of land, introduction of other crops and livestock extension (Manson et al., 2008). However, the coffee agroecosystem is considered as one of the few arboreal reserves in the area that serve as economic and environmental insurance (Ávila B., C.H., Martínez M., M., Jaloma C., J. M., \& Rodríguez O., N., 2005); since they preserve the original vegetation, provide refuge to wildlife and contribute to the economy of peasant families (Moguel \& Toledo, 2004; García Mayoral E., Valdez Hernández, J. I., Luna Cavazos, M., \& López Morgado, R., 2015), because food and medicinal usage contribute to health, nutrition and the culinary tradition of the locality. The diversity of products in the coffee plantation improve the families' diet while its sale enables monetary income (Ortega Ortega, T., Vazquéz García, L., López Mata V., \& Zapata Martelo, E., 2014). This work pretends to 1 ) identify shade tree species, 2) estimate alpha and beta diversity indices, and 3) describe the traditional use of tree species in agroecological coffee plantations in the municipalities of Amatlán de los Reyes and Ixhuatlán del Café, as well as to know the current state of the diversity and visualize the impact of coffee plantation management on the arboreal diversity in order to identify proposals focused on social development with environmental, food, social and gender justice (Perfecto I., Mas A.H., Dctsch T., \& Vandermeer J. 2003, Ávila et al., 2005, Zuluaga, S., Catora-Vargas, G., G. P., \& Siliprandi, E. 2018).

\section{Materials and methods}

This research was carried out in agroecological coffee plantations in communities of Guzmantla, Crucero de Zapata, Plan de Ayala and Ixhuatlán del Café belonging to the municipality of Ixhuatlán del Café (IXC) at an altitudinal range of $1100 \mathrm{~m}$ to 1300 masl and in Amatlán de los Reyes (AMR) at an altitudinal range of $700 \mathrm{~m}$ to 800 masl (INEGI, 2018). Both municipalities are located in the central mountainous mantenimiento de la biodiversidad para promover el equilibrio entre la producción y la conservación del ecosistema, además, aprovecha la riqueza arbórea que se traduce en beneficios ambientales, económicos, sociales y culturales como la construcción de la soberanía alimentaria (Sevilla-Guzmán \& Woodgate, 2013; Martínez-Torres \& Rosset, 2015).

En Veracruz se estima una pérdida del $40 \%$ del bosque mesofilo de montaña, principalmente por cambio en el uso de suelo, introducción de otros cultivos y extensión de la ganadería (Manson et al., 2008). Sin embargo, el agroecosistema café es considerado, una de las pocas reservas arbóreas de la zona que fungen como seguros económicos y ambientales (Ávila B., C.H., Martínez M., M., Jaloma C., J. M., \& Rodríguez O., N., 2005); ya que conservan la vegetación original, aportan refugio para la vida silvestre $y$, también contribuyen a la economía de las familias campesinas (Moguel \& Toledo, 2004; García Mayoral E., Valdez Hernández, J. I., Luna Cavazos, M., \& López Morgado, R., 2015), ya que los usos alimenticios y medicinales contribuyen a la salud, nutrición y tradición culinaria de la localidad. La diversidad de los productos del cafetal mejora la dieta de las familias, mientras que su venta permite la obtención de ingresos monetarios (Ortega Ortega, T., Vazquéz García, L., López Mata V., \& Zapata Martelo, E., 2014). Este trabajo pretende: 1) identificar las especies de árboles de sombra; 2) estimar los índices de diversidad alfa y beta $y$, 3) describir el uso tradicional de las especies arbóreas en cafetales agroecológicos de los municipios de Amatlán de los Reyes e Ixhuatlán del Café, así como conocer el estado actual de la diversidad y visibilizar el impacto que tiene el manejo del cafetal sobre la diversidad arbórea para identificar propuestas enfocadas a un desarrollo social con justicia ambiental, alimentaria, social y de género (Perfecto I., Mas A.H., Dctsch T., \& Vandermeer J. 2003, Ávila et al., 2005, Zuluaga, S., Catora-Vargas, G., G. P., \& Siliprandi, E. 2018).

\section{Materiales y métodos}

La presente investigación se realizó en cafetales agroecológicos de las comunidades de Guzmantla, Crucero de Zapata, Plan de Ayala e Ixhuatlán del Café, pertenecientes al municipio de Ixhuatlán del Café (IXC) en un rango altitudinal de $1100 \mathrm{~m}$ a 1300 msnm y en Amatlán de Los Reyes (AMR), en un rango 
region of the state of Veracruz, which corresponds to montane cloud forest. The study area has humid semitemperate weather with heavy rainfall in the summer $A C(m)$, and humid semi-temperate of the group $A C(m)$ (f) with mid temperatures between 18 and $22^{\circ} \mathrm{C}$ and a precipitation from 1800 to $2000 \mathrm{~mm}$ and from 2000 to 2500 mm (García-CONABIO, 1998) (Map 1).

Data used in this study were obtained from the project "Manejo del sistema agroecológico forestal del cafetal en localidades de las subcuencas de los ríos La Antigua y Jamapa", started in 2015 and directed by the organization Vinculación y Desarrollo Agroecológico de Café A.C. (VIDA A.C.). Under this dynamic, community promotors and members of VIDA A.C. applied a questionnaire of 44 questions to obtain general information about the coffee plantations. For the inventory, four sample areas of $50 \mathrm{~m}^{2}(25 \mathrm{~m}$ long by $2 \mathrm{~m}$ wide) were located considering greater variability of the land. Information gathering was based on the methodology of agroforest inventory, according to Geilfus (2009). The work was carried out in groups of family members of each one of the coffee plantations. Additionally, in each coffee plantation a list of all the shade trees was elaborated with the altitudinal de $700 \mathrm{~m}$ a $800 \mathrm{msnm}$ (INEGl, 2018). Ambos municipios se ubican en la región montañosa central del estado de Veracruz, la cual corresponde al bosque mesófilo de montaña. El área de estudio presenta un clima semicálido húmedo con abundantes Iluvias en verano $A C(m)$, y semicálido húmedo del grupo A C (m) (f) con temperaturas media de 18 a $22^{\circ} \mathrm{C}$ y una precipitación de 1800 a $2000 \mathrm{~mm}$ y de 2000 a 2500 mm (García-CONABIO, 1998) (Mapa 1).

Los datos empleados en este estudio fueron obtenidos del proyecto "Manejo del sistema agroecológico forestal del cafetal en localidades de las subcuencas de los ríos La Antigua y Jamapa", iniciado en 2015 y liderado por la organización Vinculación y Desarrollo Agroecológico de Café A.C. (VIDA A.C.). En esta dinámica, promotores comunitarios e integrantes de VIDA A.C. aplicaron un cuestionario de 44 preguntas para obtener información general sobre sus cafetales. Para el inventario, en cada cafetal se ubicaron cuatro áreas escalonadas de $50 \mathrm{~m}^{2}$ ( $25 \mathrm{~m}$ de largo por $2 \mathrm{~m}$ de ancho), considerando la mayor variabilidad del terreno. La obtención de la información se basó en la metodología del inventario agroforestal, de acuerdo

Map 1. Location of the municipalities under study, Veracruz, Mexico

Mapa 1. Localización de los municipios en estudio, Veracruz, México.

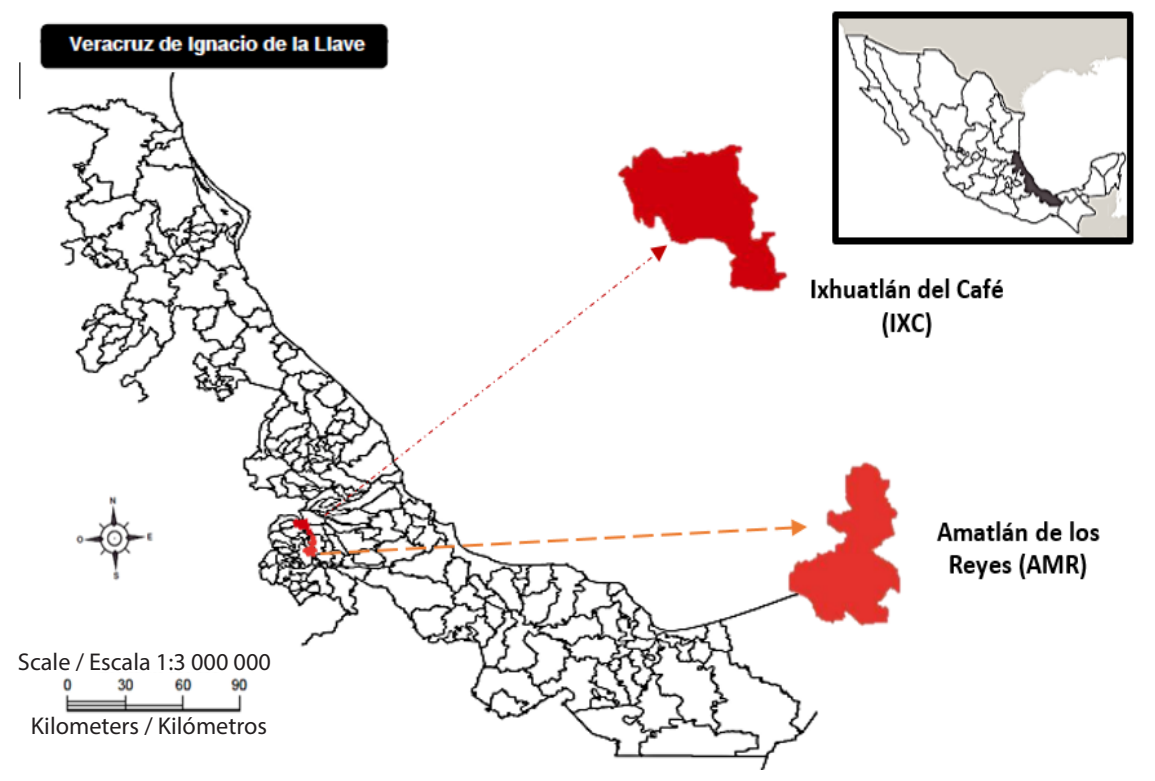

Source: INEGI, 2018. Marco Geoestadístico.

Fuente: INEGI, 2018. Marco Geoestadístico. 
local name indicated by the informants of the family group; the number of individuals per species and its main uses were quantified. Flowers and leaves were also collected for botanical identification (García \& Casado, 2008). The taxonomic determination of the species was carried out with samples from the herbarium of the Instituto de Ecología (INECOL) in Xalapa, Veracruz (IE-XAL).

Richness of species was estimated with the program Estimates Win (8.2) and the accumulation curve of species was generated for each municipality. The Chao 2 estimator was also obtained, which, according with Conwell (2013), calculates the total amount of species that could be found in a locality. The richness of tree species found in the coffee plantations was estimated considering each one as sample units (average size of 3 ha in AMR and $1 \mathrm{Ha}$ in IXC), 16 coffee plantations were inspected ( $51.4 \mathrm{ha}$ ) in the municipality of Amatlán de Los Reyes (AMR) and 84 coffee plantations ( $223.3 \mathrm{ha}$ ) in the municipality of Ixhuatlán del Café (IXC).

The diversity of species in each municipality was estimated with the Shannon-Weiner index using the program EstimateS Win (8.2). The diversity index is a statistical estimation that considers the abundance of each species and how uniform is its distribution (Magurran, 2004). The turnover rate of shade tree species in coffee plantations of each municipality was also estimated ( $\beta$ diversity), in order to do so, the Jaccard index was obtained, which indicates the species shared among locations; if the Jaccard index value is 0 , it indicates that the locations do not share species and if the value is 1 , they share all the species (Rangel-Ch, 2015). Finally, the ecological significance of shade trees in coffee plantations was also determined and included in the analysis. It was estimated taking into consideration the average values of density and relative frequency of shade trees in the sampled coffee plantations, this index enables comparing the ecological weight of the species within the plant community

\section{Results and discussion}

\section{Inventory and richness of species}

In the municipality of AMR, in 16 coffee plantations, 48 shade tree species were registered (I.C.=37.3-58.6; con Geilfus (2009), se trabajó en forma grupal con miembros de las familias en cada uno de los cafetales. Asimismo, en cada cafetal se elaboró una lista de todos los árboles de sombra con el nombre local indicado por los informantes del grupo familiar; se cuantificó el número de individuos por especie y los principales usos. Además, se colectaron hojas y flores para su posterior identificación botánica (García \& Casado, 2008). La determinación taxonómica de las especies se realizó a partir de ejemplares del herbario en el Instituto de Ecología (INECOL) en Xalapa, Veracruz (IE-XAL).

La riqueza de especies se estimó con el programa EstimateS Win (8.2) y se generó la curva de acumulación de especies para cada municipio. Además, se obtuvo el estimador Chao 2 que, de acuerdo con Colwell (2013), calcula el total de especies que podrían encontrarse en cada localidad. La riqueza de especies de árboles encontrada en los cafetales se realizó considerando cada uno como unidad de muestreo (tamaño promedio de 3 ha en AMR y 1 ha en IXC), en total se inspeccionaron 16 cafetales (51.4 ha) en el municipio de Amatlán de Los Reyes (AMR), y 84 cafetales (223.3 ha) en el municipio de Ixhuatlán del Café (IXC).

Para estimar la diversidad de especies en cada municipio se empleó el índice de diversidad Shannon-Wiener, mediante la utilización del programa EstimateS Win (8.2). El índice de diversidad es una estimación estadística que toma en cuenta la abundancia de cada especie y qué tan uniformemente se encuentran distribuidas (Magurran, 2004). Por otra parte, también se estimó la tasa de recambio de las especies de árboles de sombra en los cafetales de cada municipio (diversidad ß) para el cual se obtuvo el índice de Jaccard, que indica las especies compartidas entre los sitios, si el valor del índice de Jaccard es 0 , indica que los sitios no comparten especies, y si es 1 comparten todas las especies (Rangel-Ch, 2015). Finalmente se incluyó en el análisis, la determinación de la importancia ecológica de los árboles de sombra en los cafetales, la cual se calculó tomando en cuenta los valores promedio de densidad y frecuencia relativa de los árboles de sombra en los cafetales muestreados, dicho índice permite comparar el peso ecológico de las especies dentro de la comunidad vegetal. 
$95 \%)$. From these species, 36 were botanically identified, nine were registered as unknown and three under the local name. From the botanically identified species, 25 botanical families were identified. The Rutaceae and Malvaceae families stood out with a richness of four species, followed by the Lauraceae family with three species and the Anacardiaceae, Fabaceae and Juglandaceae families with two species; 19 more families presenting only one species were registered.

In the coffee plantations, in the municipality of IXC, a richness of 102 tree species was estimated (I.C.=87.8-116.1; $95 \%$ ). From the total of species, 63 were botanically identified, 31 were registered as unknown and eight with the common name assigned by the coffee plantation families. The species belong to 35 botanical families. The Rutaceae family stood out with six species; Fabaceae and Malvaceae with five species; Lauraceae, Rosaceae and Solanaceae with four species; Anacardiaceae with three species, and Bignoniaceae, Euphorbiaceae, Juglandaceae and Meliaceae with two species. The 24 remaining families presented only one species.

From the inventory of botanically identified trees, it was found that in AMR, $66.6 \%$ are native species, 2.7 $\%$ are endemic and $30.5 \%$ are introduced. Among the introduced species orange (Citrus sinensis) and mango (Mangifera indica) stood out. In IXC $55.5 \%$ of the species found are native, $9.5 \%$ are endemic and $33.3 \%$ are introduced species. The walnut tree (Juglans pyriformis) and canilla (Litsea sp.) are the most abundant species.

The species accumulation curve was not asymptote in both municipalities, this means that if the sampling effort was to increase, the richness of species can increase. The Chao 2 index estimates that in AMR 110 species could be registered (I.C. $=71.8-210 ; 95 \%)$. While in IXC the Chao 2 index indicates that there could be up to 199 species in the region (I.C.=148-306; $95 \%$ ) (Figure 1).

Comparison of the accumulation curves of species, with a sampling effort of 16 coffee plantations, shows that the species richness is statistically the same in both municipalities $(P>0.05)$.

\section{a diversity}

For AMR, the average value ( \pm d.s.) of the Shannon index was $3.04 \pm 0.001$, while in IXC it was $3.59 \pm 0.001$, with a sampling effort of 16 and 84 coffee planta-

\section{Resultados y discusión}

\section{Inventario y riqueza de especies}

En el municipio de AMR, en 16 cafetales se registraron 48 especies de árboles de sombra (I.C.=37.3-58.6; 95 \%). De estas especies, 36 fueron identificadas botánicamente, nueve se registraron como desconocidas y tres con el nombre local. De las especies identificadas botánicamente, se registró un total de 25 familias botánicas, destacando las familias Rutaceae y Malvaceae con una riqueza de cuatro especies, siguió la familia Lauraceae con tres especies, y las familias Anacardiaceae, Fabaceae y Juglandaceae con dos especies; se registraron 19 familias más que solo presentaron una sola especie. En los cafetales del municipio de IXC, se estimó una riqueza de 102 especies arbóreas (I.C.=87.8-116.1; $95 \%)$. Del total de especies, 63 fueron identificadas botánicamente, 31 se registraron como desconocidas y ocho con el nombre común asignado por las familias cafetaleras. Las especies pertenecen a 35 familias botánicas, destacando la familia Rutaceae con seis especies; Fabaceae y Malvaceae con cinco especies; Lauraceae, Rosaceae y Solanaceae con cuatro especies; Anacardiaceae con tres especies y Bignoniaceae, Euphorbiaceae, Juglandaceae y Meliaceae con dos especies. Las 24 familias restantes presentaron solo una especie.

A partir del inventario de árboles identificados botánicamente, se encontró que en AMR, $66.6 \%$ son especies nativas, $2.7 \%$ son endémicas y $30.5 \%$ son introducidas. Entre las especies introducidas destacan la naranja (Citrus sinensis) y el mango (Mangifera indica). En IXC $55.5 \%$ de las especies encontradas son nativas, $9.5 \%$ son endémicas y $33.3 \%$ son especies introducidas. EL nogal (Juglans pyriformis) y la canilla (Litsea sp.) son las especies más abundantes.

La curva de acumulación de especies, no resultó asintótica en ambos municipios lo que indica, que de incrementar el esfuerzo de muestreo, la riqueza de especies puede aumentar. El índice Chao 2 estima que en AMR podría registrarse hasta 110 especies (I.C. $=71.8-210 ; 95$ \%). Mientras que en IXC el índice Chao 2 indica que en la región podría haber hasta 199 especies (I.C.=148-306; $95 \%$ ) (Figura 1). 
Figure 1. Accumulation curve of shade trees and non-parametric estimators of species richness (logarithmic trendline) with the Chao 2 index in agroecological coffee plantations in the municipalities of Amatlán de Los Reyes (AMR) and Ixhuatlán del Café (IXC), Veracruz.

Figura 1. Curva de acumulación de árboles de sombra y estimadores no paramétricos de la riqueza de especies (línea de tendencia logarítmica) con el índice de Chao 2 en cafetales agroecológicos de los municipios de Amatlán de los Reyes (AMR) e Ixhuatlán del Café (IXC), Veracruz.

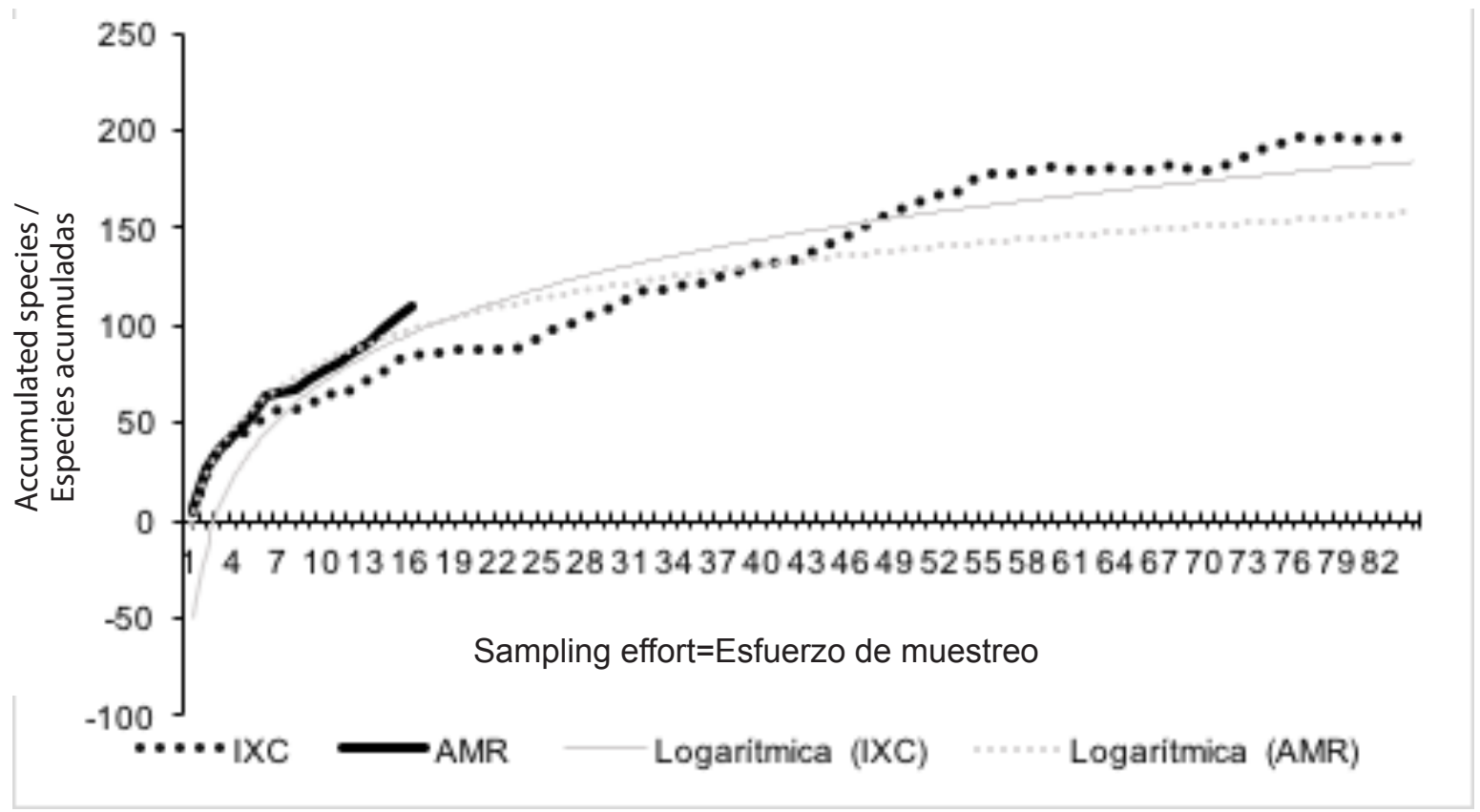

Chao 2. Non-parametric estimator of species richness. Logarithmic: trendline in the accumulation curve of species.

Chao 2. Estimador no paramétrico de la riqueza de especies. Logarítmica: línea de tendencia en la curva de acumulación de especies.

tions respectively. When comparing the index with a sampling effort of 16 coffee plantations, the diversity of species was similar in both localities (3.16 \pm 0.11 for IXC and $3.04 \pm 0.001$ for AMR).

\section{$\beta$ diversity}

The minimum value of the Jaccard index for AMR was zero and the maximum was 0.5 with an average of $0.14 \pm$ d.s. Most of the comparisons (18\%) show a Jaccard index value of 0 and a maximum of 0.5 . It was seen in less than $3 \%$ of the cases. It is also seen that in IXC, coffee plantations share a small number species. Regarding IXC, the Jaccard index had an average value of \pm s.d. $0.11 \pm 0.10$, the minimum value was 0 and the maximum was 0.7 . It is important to mention that more than $30 \%$ of the comparisons among coffee plantations have a value of 0 , which means that they do not share species.
La comparación de las curvas de acumulación de especies muestra que, con un esfuerzo de muestreo de 16 cafetales, la riqueza de especies es estadísticamente igual en los dos municipios $(P>0.05)$.

\section{Diversidad a}

Para AMR, el valor promedio ( \pm d.s.) del índice de Shannon fue de $3.04 \pm 0.001$, mientras que en IXC fue de $3.59 \pm 0.001$, con un esfuerzo de muestreo de 16 y 84 cafetales, respectivamente. Al comparar el índice con base en un esfuerzo de muestreo de 16 cafetales, se observó que la diversidad de especies es similar en ambas localidades $(3.16 \pm 0.11$ para IXC y $3.04 \pm 0.001$ para AMR).

\section{Diversidad $\beta$}

Para el caso de AMR el valor mínimo del índice de Jaccard, fue de cero y el valor máximo fue de 0.5 


\section{Ecological importance}

In AMR, the species with the highest ecological value were, xochicahuitl (Cordia alliodora), chalahuite (Inga vera) and orange (C. sinensis) and avocado (Persea americana) with approximate values of 38, 23, 11 and 10 respectively. The remaining 35 taxonomically determined species showed values of ecological importance between 75 and 1.5 (Figure 2)

The structure of the calahuite enables higher density of coffee plantations per unit of area, it also fixates nitrogen into the soil; while orange and the avocado were sown for the economic value they represent (Delgado et al., 2018).

For IXC, the calahuite (I. vera) represents the highest value of ecological importance (60) followed by avocado (Persea americana) (25) and ixpepe (Trema micrantha) (17) as well as xochicahuitl (Cordia alliodora). The remaining 42 species have values that go from 15 to 0.5 (Figure 3).

The trees with the lowest ecological importance values are close to 1 , from which 12 species were identified for AMR and for this study case, they were divided according to its origin, native and introduced. con un promedio de $0.14 \pm$ d.s. La mayoría de las comparaciones (18\%) presentan un valor del índice de Jaccard de 0 y el valor máximo de 0.5 se presentó en menos del $3 \%$ de los casos. De igual forma, en IXC se observa que los cafetales comparten un número reducido de especies. En el caso de IXC el índice de Jaccard fue un valor promedio de \pm s.d. $0.11 \pm 0.10$, el valor mínimo fue de 0 y el valor máximo fue de 0.7. Es importante señalar que más del $30 \%$ de las comparaciones entre cafetales tuvieron un valor de 0 , lo que indica que no comparten especies.

\section{Importancia ecológica}

En AMR la especie con mayor valor de importancia ecológica, fueron xochicahuitl (Cordia alliodora), chalahuite (Inga vera) y naranja (C. sinensis) y aguacate (Persea americana) con valores aproximados de 38, 23,11 y 10 , respectivamente. El resto de las 35 especies con determinación taxonómica presentaron valores de importancia ecológica entre 75 y 1.5 (Figura 2).

La estructura del chalahuite permite mayor densidad de cafetales por unidad de superficie, además de fijar nitrógeno en el suelo; mientras que la

Figure 2. Ecological importance according to density and relative frequency of tree species in agroecological coffee plantations of Amatlán de los Reyes (AMR).

Figura 2. Importancia ecológica de acuerdo con la densidad y frecuencia relativa de las especies arbóreas en cafetales agroecológicos de Amatlán de los Reyes (AMR).

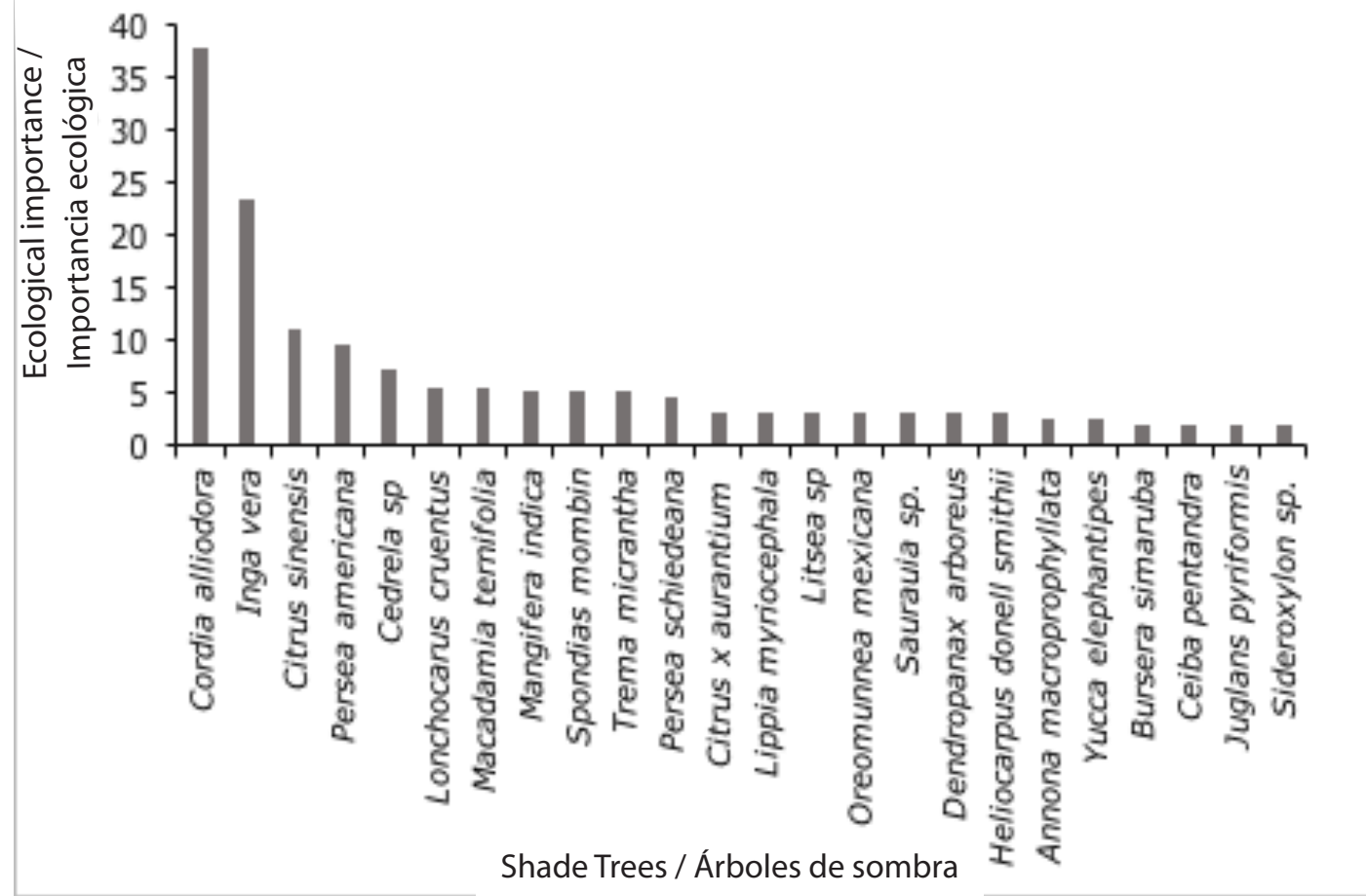


Figure 3. Ecological importance according to density and relative frequency of tree species in agroecological coffee plantations of Ixhuatlán del Café (IXC).

Figura 3. Importancia ecológica de acuerdo con la densidad y frecuencia relativa de las especies arbóreas en cafetales agroecológicos de Ixhuatlán del Café (IXC).

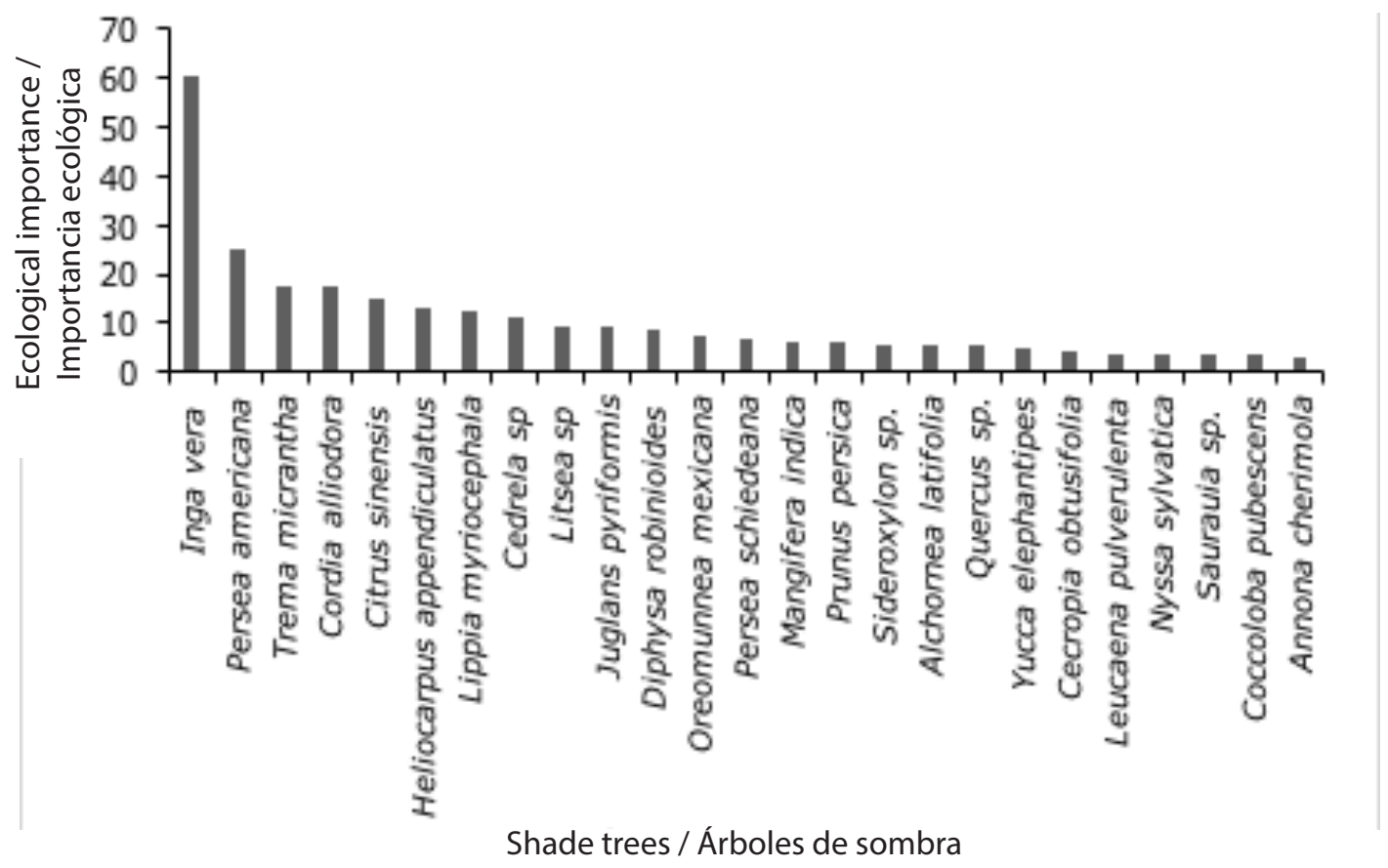

The native trees are chiquite (Hampea sp.), coralillo (Coccoloba pubescens), guava (Psidium guajava), gordolobo (Bocconia frutescens), jonote (Heliocarpus appendiculatus), manzanillo (Nyssa silvatica), sopa de pan (Alchornea latifolia), zapote (Casimiroa sp.) and zapote negro (Diospyros digyna); among the introduced species are peach (Prunus persica), oak tree (Quercus sp.) and key lime (Citrus aurantifolia). This is the same pattern seen in IXC, where 19 shade tree species show ecological importance values lower than 1, among which the native species that stand out are ceiba (Ceiba pentandra), equimite (Erythrina americana), floripondio (Brugmansia arborea), gordolobo (B. frutescens), huevo de chango (Stemmadenia donnell-smithii), marangola (Clethra mexicana), mulato (Bursera simaruba), ramatinaja (Trichilia havanensis), tepozán (Buddleja cordata), zempalegua (Ulmus mexicana); regarding introduced trees, the capulincillo (Prunus serotina), flor de mayo (Pericallis hadrosoma), gravilea (Grevillea robusta), key lime (C. aurantifolia), naranjo mandarina (Citrus $\times$ reticulata), apple (Pyrus malus), níspero (Eriobotrya japonica) and primavera (Tabebuia chrysantha) were identified. naranja y el aguacate fueron sembrados por el valor económico que representan (Delgado et al., 2018).

Para el caso de IXC, el chalahuite (I. vera), es la que presenta el mayor valor de importancia ecológica (60) seguido del aguacate (Persea americana) (25) e ixpepe (Trema micrantha) (17) al igual que (Cordia alliodora). Las 42 especies restantes tiene valores que van de 15 a 0.5 (Figura 3).

Los árboles con los valores de importancia ecológica más bajos, son cercanos a 1, de las cuales se identifican 12 especies para AMR y para este caso de estudio, se dividieron de acuerdo a su origen, nativas e introducidas. Los árboles nativos identificados son el chiquite (Hampea sp.), coralillo (Coccoloba pubescens), guayaba (Psidium guajava), gordolobo (Bocconia frutescens), jonote (Heliocarpus appendiculatus), manzanillo (Nyssa silvatica), sopa de pan (Alchornea latifolia), zapote (Casimiroa sp.) y zapote negro (Diospyros digyna); entre las especies introducidas se identifica al durazno (Prunus persica), encino (Quercus sp.) y limón agrio (Citrus aurantifolia). Este patrón se repite en IXC, donde 19 especies de árboles de sombra presentan valores de importancia ecológica menores a 1, entre las 


\section{Diversity in the studied municipalities}

The identified shade tree species in both municipalities (AMR and IXC) are related with high Shannon-Wiener diversity indices. It was found in the analysis that by adding up the identified species in each coffee plantation. A great diversity is obtained at a municipality level, with an extension of 51.4 and 223.3 ha in AMR and IXC respectively. However, when small scale samples of diversity are taken, that is, a coffee plantation per family, they can share very few species among them, therefore diversity is low. Similar studies about diversity and traditional use of shade trees in coffee plantations of Veracruz show high richness of species in the region of CoatepecHuatusco. Travieso-Bello and Ros (2011) identified 52 families, 102 genera and 154 species of shade trees, while in Xochitlán, 67 species were found in 20 sampled coffee plantations (Martínez et al., 2007). In addition, the use of firewood is recognized as the main energy resource, hence the number of species registered under this classification, most of which are for self-consumption (Hernández et al., 2012, JassoArriaga, 2019).

Variation in management of coffee plantations shows that the classic diversity indices are limited. Two arboreal communities or plantations can have the same number of species and abundance of trees, however, the species are different in each coffee plantation when considering spatial, biotic and sociocultural differences (Florez et al., 2002; Manson et al., 2008). Even though the indices are useful to estimate the number of species in a habitat, and they express the turnover between two places, on their own, they are not able to visualize the territorial influence in the composition of the landscape. Changes in vegetation depend on economic and cultural needs (Manson et al., 2008), and environmental, specifically in the case of the organization VIDA A.C.

The introduction of species as well as management practices focused on productivity and economic profit have benefited coffee plantations, however, the needs, and traditional knowledge haven't been considered (Martínez-Torres \& Rosset M., 2015). Even with all the evidence and studies reporting on the benefits and multifunctionality of shade trees at an ecological and social level, there is cuales destacan como especies nativas la ceiba (Ceiba pentandra), equimite (Erythrina americana), floripondio (Brugmansia arborea), gordolobo (B. frutescens), huevo de chango (Stemmadenia donnellsmithii), marangola (Clethra mexicana), mulato (Bursera simaruba), ramatinaja (Trichilia havanensis), tepozán (Buddleja cordata), zempalegua (Ulmus mexicana); en cuanto a árboles introducidos se identificó al capulincillo (Prunus serotina), flor de mayo (Pericallis hadrosoma), gravilea (Grevillea robusta), limón agrio (C. aurantifolia), naranjo mandarina (Citrus $\times$ reticulata), manzano (Pyrus malus), níspero (Eriobotrya japonica) y primavera (Tabebuia chrysantha).

\section{Diversidad en los municipios de estudio}

Las especies de árboles de sombra identificados en los dos municipios (AMR e IXC), están relacionados con los altos índices de diversidad de ShannonWiener estimados. En este análisis se encontró que al ir sumando las especies identificadas en cada cafetal se alcanza una gran diversidad a nivel del municipio, con una extensión de 51.4 y 223.3 hectáreas en AMR e IXC, respectivamente. Sin embargo, al tomar muestras de diversidad a escala más pequeña, es decir a nivel de cafetal por familia, estos pueden llegar a compartir muy pocas especies entre ellos, por lo cual la diversidad resulta más baja. Estudios similares sobre la diversidad y uso tradicional de los árboles de sombra en cafetales de Veracruz, reportan alta riqueza de especies, en la región de CoatepecHuatusco. Travieso-Bello y Ros (2011) identificaron 52 familias, 102 géneros y 154 especies de árboles de sombra, mientras que, en Xochitlán, se encontraron 67 especies en 20 plantíos muestreados (Martínez et al., 2007). Asimismo, se reconoce el uso de leña como el principal recurso energético, de ahí el número de especies registradas en esta clasificación, las cuales en su mayoría son para autoconsumo (Hernández et al., 2012, Jasso-Arriaga, 2019).

La variación en el manejo de los cafetales muestra que los índices de diversidad clásicos son limitados. Dos comunidades arbóreas o plantaciones pueden tener el mismo número de especies y abundancia de árboles, sin embargo, las especies son diferentes en cada cafetal al considerar la diferencia espacial, biótica y sociocultural (Florez et al., 2002; Manson 
still a need for public policies to help maintain and preserve the biodiversity (Willliams-Linera, Manson, H., R., \& Isunza V., E., 2002; Zuluaga, 2002).

Nowadays, the introduction of transnational enterprises in Mexico promote the intensification of coffee with improved varieties and species of high productivity which are grown at full sunlight. It promotes the modification and deforestation of diversified shade coffee plantations, and it fragments cloud forest (Williams-Linera, et al., 2002). A future line of action, is the implementation of restauration and diversification plans and programs for coffee plantations stimulating reforestation according to the needs and preferences of the coffee plantation families, taking into consideration native trees, even though they predominate over introduced species, are less frequent and abundant in the sampled coffee plantations.

From the identified trees, two species are reported in the list of species at risk of the Official Mexican Standard NOM-059-SEMARNAT-2010, the primavera (T. chrysantha) and zopilote (Oreomunnea mexicana), under the status of endangered species (SEMARNAT, 2010). The primavera (T. chrysantha) is a widely distributed tree; it is an important resource for pollinator species and for its wood, which has the advantage of being durable and termite resistant (Pennington \& Sarukhán, 1998). While the palo de zopilote (O. mexicana) is a relict tree that arose 23 million years ago and its distribution is restricted to the states of Oaxaca and Veracruz (Narave, 1983; Pacheco-Cruz et al., 2018).

\section{The use of shade trees}

Tree species are used at different moments in both municipalities to cover emergent necessities such as fuel, food, construction and medicine. In AMR 33 trees that are used were registered (91.6\%): 18 for fuel $(50 \%), 17$ edible trees ( $42.2 \%), 15$ for construction (41.6\%) and three medicinal (8.3\%). In the municipality of IXC, 60 species of trees are used (95\%). Forty-three are used for firewood (68.2\%), 34 edible (53.9\%), 31 for construction (49.2\%) and 29 medicinal (46\%). Shade trees in coffee plantations are multifunctional elements, available throughout the year, from which leaves, flowers, fruits and bark are used. Therefore, it is important to analyze the et al., 2008). Si bien, los índices ayudan a estimar el número de especies en un hábitat y expresar el recambio entre dos lugares, por sí solos, no alcanzan a visibilizar la influencia territorial en la composición del paisaje, pues los cambios de vegetación dependen de las necesidades económicas y culturales (Manson et al., 2008), y ambientales para el caso específico de la organización VIDA A.C.,

La introducción de especies, así como las prácticas de manejo enfocadas en la productividad y ganancia económica beneficiaron al cultivo de café, sin embargo, no consideraron las necesidades ni el conocimiento tradicional de las familias cafetalera sobre su territorio (Martínez-Torres \& Rosset M. 2015). Aun con todas las evidencias y estudios que reportan los beneficios y multifuncionalidad de los árboles de sombra a nivel ecológico y social, hacen falta políticas públicas que ayuden al mantenimiento y conservación de la biodiversidad (Willliams-Linera, Manson, H., R., \& Isunza V., E., 2002; Zuluaga, 2002).

Actualmente, la introducción de empresas trasnacionales en México, promueve la intensificación del café con variedades y especies mejoradas, de alta productividad que se desarrollan a pleno sol, incitando a la modificacion y deforestación del cafetal con sombra diversificada y fragmentos del bosque de niebla (Williams-Linera, et al., 2002). Una futura línea de acción, es la implementación de planes y programas de restauración y diversificación del cafetal que incentiven la reforestación de acuerdo a las necesidades y preferencias de las familias cafetaleras, considerando los árboles nativos, los cuales, a pesar de dominar sobre las especies introducidas, son poco frecuentes y abundantes en los cafetales muestreados.

De los árboles identificados, dos especies están reportados en la lista de especies en riesgo de la Norma Oficial Mexicana NOM-059-SEMARNAT-2010, la primavera (T. chrysantha) y zopilote (Oreomunnea mexicana) con estatus de especies amenazadas (SEMARNAT, 2010). La primavera (T. chrysantha) es un árbol de amplia distribución; es un recurso importante para especies polinizadoras, y su madera tiene la ventaja de ser durable y resistente a las termitas (Pennington \& Sarukhán, 1998). Mientras que el palo zopilote (O. mexicana) es un árbol relicto que surgió hace 23 millones de años y su distribución 
main traditional uses of the medicinal species from a gender perspective. Studies have reported that the women's vision has enrichened traditional uses and the importance of coffee plantations (Zuluaga et al., 2018). Regarding the coffee plantations families of VIDA A.C. integrating this study, through exchange of knowledge and training workshops managed to establish an herbal line called "mujer que sana".

For future research, we recommend that the estimated diversity indices should be complemented with studies of different approaches and in diverse scales, in addition to know the historic processes and collective actions that impact the territory and have changed the arboreal structure of the coffee plantation. One proposal is the approach under landscape analysis because it is important to analyze the effect of landscape variables in the biodiversity within the coffee plantations and consider its regional context (Perfecto et al., 2003, Muñoz, 2012, Órtiz, A., M. I., Tamayo P., L. M. O., \& Villaseñor F., A. 2014).

Vinculación y Desarrollo Agroecológico de Café A.C. (VIDA A.C.) has promoted agroecological practices in coffee plantations, taking into account the arboreal diversification, re-appropriation of traditional uses. The inventory carried out by the families integrating the organization, enabled the assessment and appropriation of knowledge and generated awareness regarding the importance of the diversity in coffee plantations as well as other elements that constitute their territory.

Maintenance of the trees in coffee plantations not only seeks to attain shade, it also seeks to promote multiple functional services for coffee plantation families and the ecosystem (Sánchez et al., 2017; Pérez-Fernández et al., 2017).

\section{Conclusions}

Thirty-three trees that are used were registered in AMR (91.6 \%): 18 for fuel (50\%), 17 edible trees (42.2 $\%), 15$ for construction ( $41.6 \%$ ) and three medicinal (8.3\%). In the municipality of IXC, 60 species of trees are used (95\%). Forty-three were identified for firewood $(68.2 \%), 34$ edible (53.9\%), 31 for construction $(49.2 \%)$ and 29 medicinal (46\%). The diversity of species at a municipality level is high according to the Shannon-Weiner index (3.04 in Amatlán de los Reyes and 3.59 in Ixhuatlán del Café), however richness of se restringe a los estados de Oaxaca y Veracruz (Narave, 1983; Pacheco-Cruz et al., 2018).

\section{Uso de los árboles de sombra}

En los dos municipios se aprovechan las especies de árboles en diferentes momentos para cubrir necesidades emergentes como combustible, alimento, construcción y medicina. En AMR se registraron 33 árboles (91.6\%) que se aprovechan: 18 para combustible (50\%), 17 árboles comestibles (42.2 \%), 15 para construcción (41.6\%) y tres medicinales (8.3\%). En el municipio de IXC, 60 especies de árboles son utilizadas (95\%). Se identificaron 43 para leña $(68.2 \%), 34$ comestibles (53.9\%), 31 para construcción (49.2\%) y 29 medicinales (46\%). Los árboles de sombra en los cafetales son elementos multifuncionales, disponibles todo el año, de los cuales se utilizan hojas, flores, frutos y corteza. Por lo que es importante analizar los principales usos tradicionales de las especies medicinales desde la perspectiva de género. Estudios han reportado que la visión de las mujeres ha permitido enriquecer los usos tradicionales e importancia del cafetal (Zuluaga et al., 2018). En el caso de las familias cafetaleras de VIDA A.C. que integraron este estudio, mediante el intercambio de saberes y talleres de capacitación lograron establecer la línea de herbolaria llamada "mujer que sana".

Para futuras investigaciones se sugiere que los índices de diversidad estimados sean acompañados por estudios con diferentes enfoques y a diversas escalas, además de conocer los procesos históricos y acciones colectivas que impactan en el territorio y que han ido cambiando la estructura arbórea del cafetal. Una propuesta es el enfoque bajo análisis de paisaje ya que es importante analizar el efecto de variables del paisaje en la biodiversidad dentro de los cafetales y considerar su contexto regional (Perfecto et al., 2003, Muñoz, 2012, Órtiz, A., M. I., Tamayo P., L. M. O., \& Villaseñor F., A. 2014).

Vinculación y Desarrollo Agroecológico de Café A.C. (VIDA A.C.) ha promovido prácticas agroecológicas en el cafetal, considerando la diversificación arbórea, reapropiación de los usos tradicionales. El inventario de los árboles realizado por las familias que integran la organización permitió la valoración y apropiación del conocimiento y 
shade trees in each coffee plantation was different, showing that an individual level (coffee plantation per family), these are not highly diversified and share a low number of species.

The composition in the diversity of shade trees in coffee plantations is associated to the priorities and needs of the coffee plantation families and gender, which at the same time depend on the social, cultural and economic conditions, where the coffee agroecosystem represents values of traditional use such as firewood, edible, construction, medicine among others; however, other aspects are also associated, such as health, in a wider sense, esthetics and recreation

\section{Acknowledgments}

To the Consejo Nacional de Ciencia y Tecnología (CONACYT); to the coffee plantation families of the organization VIDA A.C. for their work and effort that transcends in generations; to Ing. Gisela Illescas Palma Agroecologist and peasant; to C.P. Denisse Guzmán Moreno for her valuable disposition to share her information, time and knowledge, and to M.C. Jorge Alvarado López for his critical review of the document.

Fin de la versión en español

\section{References / Referencias}

Ávila B., C. H., Martínez M., M., Jaloma C., J. M., \& Rodríguez O., N. (2005). Paradigmas en la investigación de cafetales marginales en Veracruz, México. Sociedades Rurales, Producción y Medio Ambiente 5(11): 53-78.

Boege, E. (2003). Protegiendo lo nuestro, manual para la gestión ambiental comunitaria, uso y conservación de la biodiversidad de los campesinos indígenas de América Latina. México, Instituto Nacional Indigenista. 165 p.

Colwell, R. K. (2013). EstimateS Statistical Estimation of Species Richness and Shared Species from Samples. Versión 9. Guía de uso hittp://viceroy. eeb.uconn.edu/estimates/

Delgado D., M., Loureiro S., J. A., \& Alcántara B., F. A. (2018). Evaluación de diversidad arbórea para selección de especies sucedáneas de generó conciencia y genera conciencia sobre la importancia de la diversidad en el cafetal y demás elementos que componen su territorio.

El mantenimiento de los árboles en el cafetal no solo busca la obtención de sombra, también busca proveer de múltiples servicios funcionales para las familias cafetaleras y el ecosistema (Sánchez et al., 2017; Pérez-Fernández et al., 2017).

\section{Conclusiones}

En AMR se registraron 33 árboles (91.6\%) que se aprovechan: 18 para combustible (50 \%), 17 árboles comestibles (42.2\%), 15 para construcción (41.6 $\%)$ y tres medicinales (8.3\%). En el municipio de IXC, 60 especies de árboles son utilizadas (95\%). Se identificaron 43 para leña (68.2 \%), 34 comestibles (53.9 \%), 31 para construcción (49.2 \%) y 29 medicinales (46 \%). La diversidad de especies a nivel municipios es alta de acuerdo con el índice de Shannon-Wiener (3.04 en Amatlán de los Reyes y 3.59 en Ixhuatlán del (afé), sin embargo, la riqueza de árboles de sombra en cada cafetal fue diferente, evidenciando que a nivel individual (cafetal por familia), estos son poco diversificados y comparten un número reducido de especies.

La composición de la diversidad de árboles de sombra en el cafetal se asocia a las prioridades y necesidades de las familias cafetaleras y por género, que a su vez dependen de la condición social, cultural y económica, donde el agroecosistema café representa valores de uso tradicionales como leña, comestible, construcción, medicina entre los principales; sin embargo, se asocian también otros aspectos como salud, en un sentido más amplio, estética y recreación.

\section{Agradecimientos}

Al Consejo Nacional de Ciencia y Tecnología (CONACYT); a las familias cafetaleras de la organización VIDA A.C. por su trabajo y esfuerzo que trasciende en generaciones; a la Ing. Gisela Illescas Palma agroecóloga y campesina; a C.P.Denisse Guzmán Moreno, por su valiosa disposición para compartir su información, tiempo y conocimiento y al M.C. Jorge Alvarado López por la lectura crítica del documento.

Fin de la versión en español 
reforestación subcuenca del Carrizal. Mikarimin. Revista Científica Multidisciplinaria 4(1): 123-136.

Florez, J. A., Muschler, R., Harvey, C., Finegan, B., \& Roubik, D. W. (2002). Biodiversidad funcional en cafetales: el rol de la diversidad vegetal en la conservación de abejas. Agroforestería en Las Américas 9(35):29-36.

Francisco-Ventura, E., Menchaca-García, R. A., Toledo-Aceves, T., \& Krömer, T. (2018). Potencial de aprovechamiento de epífitas vasculares caídas en un bosque mesófilo de montaña de Los Tuxtlas, Veracruz, México. Revista Mexicana de Biodiversidad 89(4): 1263-1279. doi.org/10.22201/ ib.20078706e.2018.4.2390 enero de 2020)

García, E.-Comisión Nacional para el Conocimiento y Uso de la Biodiversidad (CONABIO). (1998). Precipitación anual, escala 1:100000. México. http:// www.conabio.gob.mx/informacion/gis/layouts/ isoyt1mgw (Consultado 27 de enero de 2020)

García, A., \& Casado, E. (2008). Estrategias y prácticas cualitativas de investigación social. Ed. Pearson Educación. Madrid, España. 346 p.

García Mayoral E., Valdez Hernández, J. I., Luna Cavazos, M., \& López Morgado, R. (2015). Estructura y diversidad arbórea en sistemas agroforestales de café en la Sierra de Atoyac, Veracruz. Madera y Bosques vol. 21 (3): 69-82

Geilfus, F. (2009). 80 herramientas para el desarrollo participativo. $8^{\mathrm{a}}$ ed., Ed. IICA. San José, Costa Rica. $217 p$.

Hernández M., F., Licona V., A. L., Pérez P., E., Cisneros S., V. M., \& Díaz C., S. (2012). Diversificación productiva café-plantas ornamentales en La Sidra, Atzacan, Veracruz. Revista de Geografía Agrícola 48-49: 39-50.

INEGI. (2018). Dirección General de Geografía y Medio Ambiente. Catálogo Único de Claves de Áreas Geoestadísticas Estatales, Municipales y Localidades https://www.inegi.org.mx/app/ cuadroentidad/AnuarioGeografico/Ver/2018 (Consultado 27 de enero de 2020).

Jasso-Arriaga, X. (2019). Principio de conservación: coexistencia entre diversidad de especies comestibles y conocimiento tradicional. Polibotánica 47:179-199. doi.org/10.18387/ polibotanica.47.13
Magurran, A. E. (2004). Measuring biological diversity. Oxford, UK: Blackwell Publishing. 256 p.

Manson, R. H., A., Contreras H., A., \& Barrera F. L. (2008). Estudios de la biodiversidad en cafetales. En: Manson, R. H., Hernández-Ortiz V., Gallina, S. y Meltreter Klaus (eds). 2008. Agroecosistemas cafetaleros de Veracruz. Biodiversidad, manejo y conservación. Instituto de Ecología A.C. Veracruz, México. 384 p.

Martínez, M. Á., Evangelista, V., Basurto, F., Martínez, M., \& Cruz-Rivas, A. (2007). Flora útil de los cafetales en la Sierra Norte de Puebla, México. Revista Mexicana de Biodiversidad 78(1): 15-40.

Martínez-Torres, M., \& Rosset M., P. (2015). Soberanía alimentaria, agroecología y recampenización. En: Pavin, R.C.(Eds). 2015. Sonerania Alimentaia (SOBAL) e Seguranca Alimentar e Nutricional (SAN) na América Latina. UFPR, Paraná, Brasil. 111 p.

Moguel, P., \& Toledo V., M. (2004). Biodiversity conservation in traditional coffee systems of Mexico. Conservation Biology 13(1):11-21.

Muñoz C., A. (2012). Guía metodológica. Estudios de paisaje. Ed. Conselleria de infraestructuras, Territorio y Medio Ambiente.Valencia, España. $172 \mathrm{p}$.

Narave, H. (1983). Juglandaceae. Flora de Veracruz. Instituto Nacional de Investigaciones sobre Recursos Bióticos. Xalapa, Veracruz, México. 31:30 p.

Ortega Ortega, T., Vazquéz García, V., López Mata, L., \& Zapata Martelo, E. (2014). El poleo: Recurso forestal no maderable de los bosques templados de Oaxaca. CONABIO.Biodiversitas. 116: 7-11

Órtiz, A., M. I., Tamayo P., L. M. O., \& Villaseñor F., A. (2014). Una propuesta metodologica para el análisis del paisaje cultural urbano en Zacatecas. Perspectiva Geográfica 19(1): 83-106.

Pacheco-Cruz, N., Clark-Tapia, R., Campos-Contreras, J. E., Gorgonio-Ramirez, M., Luna-Krautlez, M. D.,..., Naranjo-Luna, F. J., (2018). Demografia de Oreomunnea mexicana (Standl). J. F. Leroy en el bosque de niebla de Sierra Juárez, Oaxaca. Madera y Bosques 24(2): 1-11. doi.org/10.21829/ myb.2018.2421509

Pennington, T. D., \& Sarukhán, J. (1998). Árboles tropicales de México. $2^{a}$ ed. Universidad Nacional Autónoma de México. Ed. Fondo de Cultura Económica. México, D.F., México. 521 p. 
Pérez-Fernández, Y., González S., M., EscamillaRobledo, V., E., Cruz-León, A., Rosas-Brugada, M., \& Ruiz-Espinoza, F. de J. (2017). Propuestas para la preservación de la vida en los cafetales en el municipio Teocelo, Veracruz. Revista de Geografía Agrícola 7(57):169-178. doi.org/10.5154/r. rga.2016.57.007

Perfecto I., Mas A. H., Dctsch T., \& Vandermeer J. (2003). Species richness along an agricultural intensification gradient: A tri-taxa comparison in shade coffe in southern Mexico. Biodiversity and Conservation 12: 1239-1252.

Rangel-Ch. (2015). La riqueza de las plantas con flores en Colombia. Botánica-Florística 37(2): 279-307. doi:http://dx.doi.org/10.15446/caldasia. v37n2.54375

Sánchez H., S., Mendoza B., M. Al. I., \& García H., R. V. (2017). Diversificación de la sombra tradicional de cafetales en Veracruz mediante especies maderables. Revista Mexicana de Ciencias Forestales 8(40): 7-17.

SEMARNAT. (2010). NORMA Oficial Mexicana NOM059-SEMARNAT-2010. Protección ambientalEspecies nativas de México de flora y fauna silvestres-Categorías de riesgo y especificaciones para su inclusión, exclusión o cambio-Lista de especies en riesgo. Secretaría del Medio
Ambiente y Recursos Naturales. Diario Oficial de la Federación. Cd. Mx., México. http://dof. gob.mx/nota_detalle.php?codigo $=5173091 \& f e c$ ha $=25 / 05 / 2019$

Sevilla-Guzmán, E., \& Woodgate, G. (2013). Agroecología: Fundamentos del pensamiento social agrario y teoría sociológica. Agroecología 8(2):27-34.

Travieso-Bello, A. C., \& Ros T., A. V. (2011). Biodiversidad en ecosistemas modificados por actividades agropecuarias. En: CONABIO (eds). 2011. La biodiversidad en Veracruz Estudio de Estado. Comisión Nacional para el Conocimiento y Uso de la Biodiversidad. Gobierno del Estado de Veracruz, Universidad Veracruzana, Instituto de Ecología A.C. Veracruz México. 541 p.

Williams-Linera, G., Manson, H., R., \& Isunza V., E. (2002). La fragmentación del bosque mesófilo de montaña y patrones de uso del suelo en la región oeste de Xalapa, Veracruz, México. Madera y Bosques 8(1): 73-89. doi.org/10.21829/ myb.2002.8113070

Zuluaga, S., G. P., Catora-Vargas, G., \& Siliprandi, E. (2018). Agroecología en femenino. Reflexiones a partir de nuestras experiencias. Ed. SOCLA. La Paz, Bolivia. $231 \mathrm{p}$. 
